\title{
9 An Augsburg Pastor's Views on Africans, the Slave Trade, and Slavery: Gottlieb Tobias Wilhelm's Conversations about Man (1804)
}

\begin{abstract}
When pondering the torments of poor Negroes, the whiplashes they have to endure, the meager food they are served, their confinement, and various other circumstances [ . . . ] - who can refrain from being astonished at the perseverance of human nature? Who will not wonder at the sight of the poor Negress [ . . . ] shackled to a weight of more than one hundred pounds? Thus she is punished by the ingenious cruelty of her master. For months during her labor, she is tied to the weight which a heavy chain fixes above her ankle. Whenever she wants to take a step, she must lift the burden upon her head. ${ }^{1}$
\end{abstract}

This quotation is not taken from a work focused on slavery and the slave trade but instead from a publication intending to popularize natural history and anthropology. In the years around 1800, the Protestant pastor Gottlieb Tobias Wilhelm (1758-1811) published nineteen volumes of Unterhaltungen aus der Naturgeschichte (Conversations about Natural History) in which he summarized the botanical and zoological knowledge of his time and made it available to a wider audience. Three volumes, published as Unterhaltungen über den Menschen (Conversations about Man) between 1804 and 1806, were explicitly devoted to human physiology and anatomy. ${ }^{2}$ Accordingly, Wilhelm used the example of the shackled female slave to illustrate "the perseverance of human nature" (die Dauerhaftigkeit der Menschennatur), or man's capacity to endure physical torment and strain.

The quoted passage is merely one of numerous instances in the first volume of the Conversations about Man (1804) that refer to Africans or address the subject of slavery. Over the course of his discussion of human nature, savagery and civilization, the unity and diversity of mankind, skin colors and "races," Wilhelm returns to these topics repeatedly. Given the prominence of Africans as well as the slave trade and slavery in the Conversations, this essay intends to explore the role and functions of these phenomena within the book. Wilhelm represents a particularly interesting case of German views on slavery since he engaged with a wide range of contemporary debates. Moreover, he wrote at a time when large amounts of information about African peoples, the Middle Passage, and plantation slavery in the Americas were becoming available to the German public in the form of (mostly translated) travelogues, abolitionist texts, journal

1 Gottlieb Tobias Wilhelm, Unterhaltungen über den Menschen, 3 vols. (Augsburg: Martin Engelbrecht, 1804-6), 1: 45. All translations in this essay are mine.

2 An additional six posthumously published volumes were written (or completed) by other authors. 
articles, and various ethnographic, anthropological, and philosophical works. ${ }^{3}$ HansJürgen Lüsebrink has pointed out that the eighteenth century saw a unique combination of geographical and cultural exploration on the one hand and philosophical reflection on these explorations on the other. ${ }^{4}$ As we will see, Gottlieb Tobias Wilhelm drew from both of these traditions.

In the decades before Wilhelm wrote his Conversations, several German authors had already demonstrated a sustained interest in the Atlantic slave trade and American slavery. Matthias Christian Sprengel (1746-1803), professor of history in Halle and a prolific writer on the extra-European world, devoted his inaugural lecture in 1779 to the origins of the African slave trade; a decade later, he edited and translated the abolitionist tracts of Alexander Falconbridge and Thomas Clarkson. ${ }^{5}$ Johann Jacob Sell (1754-1816), a high school teacher in Stettin (Szczecin), published a history of the slave trade in $1791,{ }^{6}$ and philosopher Christoph Meiners (1747-1810) from Göttingen advanced his views on the inferiority of Africans as well as his arguments against abolition and emancipation in several essays at roughly the same time. ${ }^{7}$

3 Karin Schüller, Die deutsche Rezeption haitianischer Geschichte in der ersten Hälfte des 19. Jahrhunderts (Cologne: Böhlau, 1992); Ute Fendler and Susanne Greilich, "Afrika in deutschen und französischen Enzyklopädien des 18. Jahrhunderts," in Das Europa der Aufklärung und die außereuropäische koloniale Welt, ed. Hans-Jürgen Lüsebrink (Göttingen: Wallstein, 2006), 113-137; Ulrike Schmieder, "Transkulturation und gender: Stereotypen von masculinity im europäischen Wissenschaftsdiskurs des 18. Jahrhunderts über Lateinamerika," Zeitschrift für Weltgeschichte. Interdisziplinäre Perspektiven 8, no. 2 (2007): 121-151, esp. 137-145. For a general background, cf. Andreas Eckert, "Aufklärung, Sklaverei und Abolition," in Die Aufklärung und ihre Weltwirkung, ed. Wolfgang Hardtwig (Göttingen: Vandenhoeck \& Ruprecht, 2010), 243-262.

4 Hans-Jürgen Lüsebrink, "Wissen und außereuropäische Erfahrung im 18. Jahrhundert," in Macht des Wissens. Die Entstehung der modernen Wissensgesellschaft, ed. Richard van Dülmen and Sina Rauschenbach (Cologne: Böhlau, 2004), 629-654, esp. 630.

5 Matthias Christian Sprengel, Vom Ursprung des Negerhandels. Ein Antrittsprogramm (Halle: Johann Christian Hendel, 1779); Matthias Christian Sprengel (ed.), Alex[ander] Falconbridges und Thomas Clarksons Bemerkungen über die gegenwärtige Beschaffenheit des Sclavenhandels und dessen politische Nachtheile für England (Leipzig: Weygand, 1790). Cf. Mark Häberlein, "Matthias Christian Sprengel als Vermittler englischer und romanischer Literatur über die außereuropäische Welt," in Halle als Zentrum der Mehrsprachigkeit im langen 18. Jahrhundert, ed. Mark Häberlein and Holger Zaunstöck (Halle: Verlag der Franckeschen Stiftungen, 2017), 215-227, esp. 215-219.

6 Johann Jacob Sell, Versuch einer Geschichte des Negersclavenhandels (Halle: Johann Jacob Gebauer, 1791).

7 Christoph Meiners, "Ueber die Rechtmässigkeit des Negern-Handels," Göttingisches Historisches Magazin 2 (1788): 398-416; Meiners, "Über die Natur der Afrikanischen Neger, und die davon abhangende Befreyung, oder Einschränkung der Schwarzen," Göttingisches Historisches Magazin 6, no. 3 (1790): 385-456; Meiners, "Historische Nachrichten über die wahre Beschaffenheit des Sclaven-Handels, und die Knechtschaft der Neger in West-Indien,” Göttingisches Historisches Magazin 6, no. 4 (1790): 645-679; Meiners, "Fortgesetzte Betrachtungen über Sclavenhandel und die Freilassung der Neger," Neues Göttingisches Historisches Magazin 2, no. 1 (1793): 1-58. Meiners' pro-slavery views prompted critical responses; see anonymous essay, "Etwas über des Herrn Hofrath Meiners Vertheidigung des Negerhandels, im Göttingischen historischen Magazin [. . .]," Beiträge zur Beruhigung und Aufklärung 2, no. 3 (1791): 642-659. 
Recent studies have emphasized that the writings of Meiners - along with those of philosopher Immanuel Kant (1724-1804), anatomist Samuel Thomas Soemmerring (1755-1830), and anthropologist Johann Friedrich Blumenbach (1755-1840) - contributed to the emergence of "scientific" racial theories in the late eighteenth century. ${ }^{8}$ In 1802, Eberhard August Wilhelm von Zimmermann (1743-1815), who taught mathematics and natural sciences at the Collegium Carolinum in Braunschweig, began to publish his Taschenbuch der Reisen (Pocketbook of Travels), a compilation of geographical, historical, and anthropological information on regions outside of Europe. The first two volumes were devoted to Africa and the West Indies. ${ }^{9}$

Viewed in this context, identification of the sources and discourses on which Wilhelm based his observations and conclusions is of particular interest. Although the Conversations about Man lack footnotes and a bibliography, the author mentions numerous writers and scholars he engaged with, demonstrating his familiarity with contemporary research and writing in philosophy, anthropology, geography, and natural history. Moreover, the illustrations accompanying the Conversations provide some clues as to Wilhelm's templates.

This also applies to the passage quoted above, in which Wilhelm refers to an image taken from John Gabriel Stedman's Narrative of a Five Years Expedition against the Revolted Negroes of Surinam, published in London in 1796 and in an abridged German translation the following year (Fig. 9.1). ${ }^{10}$ A number of illustrations created by William Blake and other engravers based on Stedman's sketches visualized the heavy

Cf. also Sabine Vetter, Wissenschaftlicher Reduktionismus und die Rassentheorie von Christoph Meiners: Ein Beitrag zur Geschichte der verlorenen Metaphysik in der Anthropologie (Aachen: Mainz, 1997); Schmieder, "Transkulturation und gender," 140-141.

8 Emmanuel Chukwudi Eze, “The Color of Reason: The Idea of 'Race' in Kant's Anthropology," in Anthropology and the German Enlightenment: Perspectives on Humanity, ed. Katherine M. Faull (Lewisburg: Bucknell University Press, 1995), 200-241; Sara Eigen and Mark Larrimore (eds.), The German Invention of Race (Albany: SUNY Press, 2006); Sarah Reimann, Die Entstehung des wissenschaftlichen Rassismus im 18. Jahrhundert (Stuttgart: Steiner, 2017). Other authors argue that the racial theories of the eighteenth century were "by-products of older religious and metaphysical frames of thought that were continued and debated." Cf. Andreas Pečar and Damien Tricoire, Falsche Freunde: War die Aufklärung wirklich die Geburtsstunde der Moderne? (Frankfurt: Campus, 2015), 83-104, quote on page 91.

9 Eberhard August Wilhelm von Zimmermann, Taschenbuch der Reisen oder unterhaltende Darstellung der Entdeckungen des 18. Jahrhunderts, in Rücksicht der Länder-, Menschen- und Productenkunde, vols. 1 and 2 (Leipzig: Gerhard Fleischer d.J., 1802-1803). On Zimmermann, see Petra Feuerstein-Herz, Der Elefant der Neuen Welt. Eberhard August Wilhelm von Zimmermann (1743-1815) und die Anfänge der Tiergeographie (Stuttgart: Deutscher Apotheker-Verlag, 2006).

10 John Gabriel Stedman, Narrative of a Five Years Expedition against the Revolted Negroes of Surinam, in Guiana, on the Wild Coast of South America: From the Year 1772, to 1777, 2 vols. (London: J. Johnson, 1796). The image of the female slave shackled to the weight is in vol. 1, opposite page 19. For the German version, see John Gabriel Stedman, Stedman's Nachrichten von Suriname und von seiner Expedition gegen die rebellischen Neger in dieser Kolonie in den Jahren 1772-1777. Ein Auszug aus dem Englischen Original, trans. C.W. Jakobs and F. Kies (Hamburg: Benjamin Gottlob Hoffmann, 


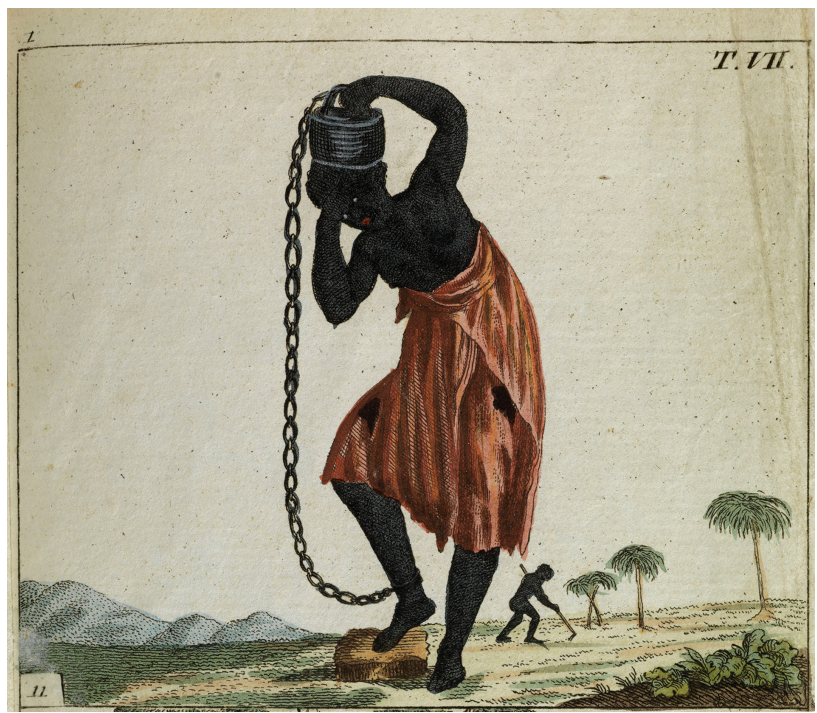

Fig. 9.1: Chained female slave, adapted from John Gabriel Stedman's Narrative of a Five Years Expedition against the Revolted Negroes of Surinam (1796). Gottlieb Tobias Wilhelm, Unterhaltungen über den Menschen (Augsburg: Martin Engelbrecht, 1804), Table VII. I would like to thank Gerald Raab (Staatsbibliothek Bamberg) for providing photographs of the images in this article.

labor and draconic punishment of slaves, including what a modern commentator has termed "lurid displays of tortured female flesh."11 Another scholar has added that "Stedman's vivid depictions of torture and bodily mutilation invite the readers to enter particular scenes by suggesting, on a subliminal level, that they actively take part in the action."12 At any rate, Wilhelm was obviously sufficiently impressed by these images that he reproduced several in his own work so as to convey to his readers a feeling for the effects of slavery.

Thus Wilhelm's Conversations about Man, which were popular during his lifetime as well as after his death, serve to highlight the importance of West Africa, the Atlantic slave trade, and American plantation slavery in the thinking of a wellinformed Southern German clergyman and popularizer of scientific knowledge. In

1797). A digital version is available from the Zentralbibliothek Zürich (permalink http://dx.doi.org/ 10.3931/e-rara-29861).

11 Tassie Gwilliam, “'Scenes of Horror,' Scenes of Sensibility: Sentimentality and Slavery in John Gabriel Stedman's Narrative of a Five Years Expedition against the Revolted Negroes of Surinam," ELH 65, no. 3 (1998): 653-673, 655; cf. also Marcus Wood, Blind Memory: Visual Representations of Slavery in England and the Americas, 1780-1865 (Manchester and New York: Manchester University Press, 2000), 230-239.

12 Mario Klarer, "Humanitarian Pornography: John Gabriel Stedman's Narrative of a Five Years Expedition Against the Revolted Negroes of Surinam (1796)," New Literary History 36, no. 4 (Autumn 2005): 559-587, quote on page 561-562. 
addition, the Conversations demonstrate how contemporary debates on the slave trade, slavery, and abolition could be dissociated from their original context and transferred into an encyclopedic work on natural history and anthropology. This process of de-contextualization and subsequent re-contextualization worked both ways, for Wilhelm's work not only borrowed from other authors but found its way into later anthologies and compilations as well. For example, his chapter on "negroes" (Neger) - a term that Wilhelm used specifically for inhabitants of West Africa, distinguishing them from "Moroccans," "Hottentots," or "Ethiopians" - was anonymously reprinted in Franz Sartori's collection of texts about America in 1818. ${ }^{13}$ In the following section, Wilhelm and his work will be introduced before the relevant passages in his Conversations about Man will be analyzed in more detail.

\section{Gottlieb Tobias Wilhelm and his Conversations about Natural History}

Like many enlightenment publications popularizing scientific knowledge, Wilhelm's work is characterized less by its originality than by its encyclopedic nature and the sheer amount of information it condenses. The author's name had largely fallen into oblivion by the mid-nineteenth century, and he remained an obscure figure until Renate Pfeuffer reconstructed his biography, the circumstances under which he produced the Conversations, and his social and intellectual environment. ${ }^{14}$

Born in 1758 in the imperial city of Augsburg as the son of a copper engraver and grandson of the publisher Martin Engelbrecht, Gottlieb Tobias Wilhelm attended the renowned St. Anna high school (Gymnasium), which had just been reformed in accordance with Enlightenment principles, and the adjacent Evangelical College from 1777 to 1781. Endowed with a scholarship from the Augsburg school office, he subsequently studied theology and philosophy at the University of Leipzig. Upon returning to Augsburg, where he would spend the remainder of his life, Wilhelm initially taught at his former high school before being appointed as preacher at the Hospital of the Holy Spirit in 1783 and eventually becoming the deacon of the former Franciscan Church zu den Barfüßern three years later. In the latter capacity, he also performed

13 Franz Sartori (ed.), Ueberlieferungen aus der Neuen Welt, oder die Staaten, Colonien und Völker jenseits des Meeres, der Schauplatz gewaltiger Ereignisse, das Augenmerk von ganz Europa [. . .] (Brno: Joseph Georg Traßler, 1818), 2:404-425 (chapter XIX).

14 Renate Pfeuffer, “. . . manchem Menschen Verdienst, Tausenden aber Belehrung und Vergnügen . . . Die 'Unterhaltungen aus der Naturgeschichte' des Pfarrers Zu den Barfüßern Gottlieb Tobias Wilhelm (1758-1811),” in Neue Forschungen zur Geschichte der Stadt Augsburg, ed. Rolf Kießling (Augsburg: Wissner, 2011), 231-278. 
pastoral duties in the local workhouse. His marriage to the daughter of a Protestant superintendent in 1787 remained without offspring.

According to Renate Pfeuffer, Wilhelm had the opportunity to study works on natural history and the popular Enlightenment in his parents' home as well as at his high school, at the University of Leipzig, and through his contacts to members of Augsburg's Protestant clergy and well-to-do citizens. One of his first publications appearing in 1791 argued that his hometown - contrary to the verdict of many Enlightenment authors - was far from being a backward, irreversibly declining imperial city that lacked the ability to reform its institutions. ${ }^{15}$ In the same year, he translated a funeral speech on the French philosopher and revolutionary Honoré-Gabriel Riquetti, Comte de Mirabeau (1749-1791). Wilhelm's sermons reflected the principles of many Protestant clergymen during the late eighteenth century: rational Christianity, the promotion of education, social responsibility, civic duties, and religious tolerance. ${ }^{16}$

Wilhelm's opus magnum, the Conversations about Natural History, were produced in the publishing house of his deceased grandfather Martin Engelbrecht, which at the time was headed by Wilhelm's brother Paul Martin. According to the author's own testimony, his undertaking benefited immensely from Joseph Paul von Cobres (1749-1823), a wealthy Catholic banker who owned an extensive natural history library and collection. ${ }^{17}$ It was at Cobres' initiative that Wilhelm was made a member of the Berlin Natural History Society (Gesellschaft naturforschender Freunde $z u$ Berlin) in 1797. Memberships in other natural history associations were to follow. In 1806, the year when Augsburg lost its status as imperial city and was incorporated into the Kingdom of Bavaria, Wilhelm rose within the ranks of the Protestant clergy to become the regular preacher at the former Franciscan church. The new Bavarian government recognized his publishing activities by awarding him the Great Gold Medal of Honor and making the Conversations about Natural History official reading at the kingdom's public schools. ${ }^{18}$

Wilhelm began his series of Conversations in 1792 with a volume on mammals, which was followed in quick succession by books on amphibians, birds, insects, fish, and worms. Following the appearance of the three volumes of Conversations about Man between 1804 and 1806 (Fig. 9.2), Wilhelm turned his attention to

15 On this debate, see Barbara Rajkay, “Totentanz oder Maskenbälle? Anmerkungen zur Geschichte Augsburgs im 18. Jahrhundert," in Augsburg, Schwaben und der Rest der Welt: Neue Beiträge zur Landes- und Regionalgeschichte. Festschrift für Rolf Kießling zum 70. Geburtstag, ed. Dietmar Schiersner, Andreas Link, Barbara Rajkay, and Wolfgang Scheffknecht (Augsburg: Wissner, 2011), 85-109 (Wilhelm is briefly mentioned on page 101).

16 Pfeuffer, "Gottlieb Tobias Wilhelm," 233-248.

17 On Cobres, see Michaela Schmölz Häberlein, “Cobres, Joseph Paul, Ritter von,” Stadtlexikon Augsburg, Augsburg: Wissner 2007, accessed October 22, 2019. https://www.wissner.com/stadtlexi kon-augsburg/artikel/stadtlexikon/cobres/3497.

18 Pfeuffer, "Gottlieb Tobias Wilhelm," 248-258. 


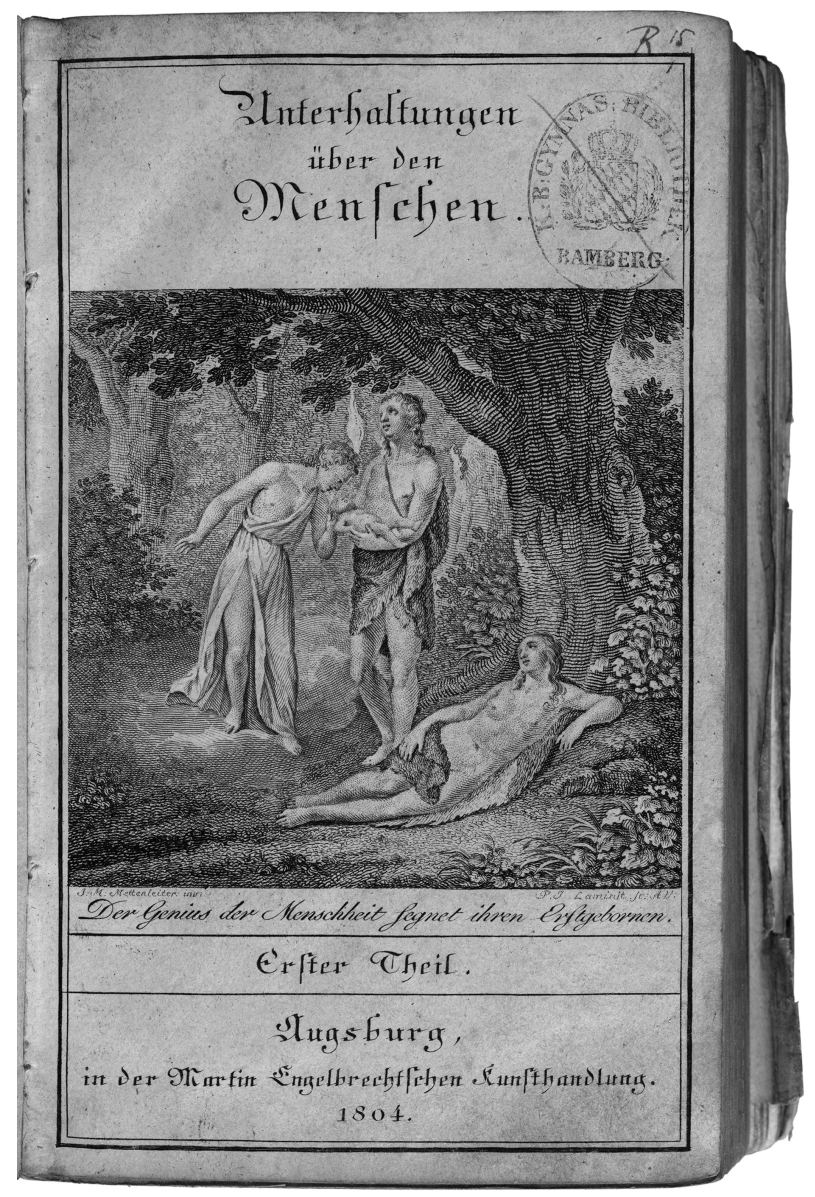

Fig. 9.2: Title page of the first volume of Wilhelm's Conversations about Man. Gottlieb Tobias Wilhelm, Unterhaltungen über den Menschen (Augsburg: Martin Engelbrecht, 1804).

botany. By the time of his death in 1811, however, only three of the ten projected volumes on plants had been published. Wilhelm's cousin, the deacon Gerhard Adam Neuhofer (1773-1816), and other authors continued the project until 1828, and the entire series was eventually reprinted in Vienna. Moreover, the Conversations were reviewed in leading contemporary journals and cited as reference works in various encyclopedias. The series was accompanied by more than 1,500 hand-colored copper plates designed by prominent Augsburg artisans. As they were published in octavo and clients had the option of paying in weekly rates, the Conversations were "a modern and affordable alternative to the lavish folio botanical and zoological 
works that had been common until the mid-eighteenth century."19 Pfeuffer studied the subscription lists for Wilhelm's works, revealing that 1,328 individuals subscribed to a total of 2,512 copies of the Conversations about Man. Slightly more than one-fifth of the subscribers resided in Augsburg, with most of the remainder hailing from Swabia, Franconia, and Saxony. ${ }^{20}$

The Conversations combined systematic instruction with stylistic vividness and clarity. "An 'omniscient' narrator carefully guided his readers through the extensive realms of nature; employing a wide range of stylistic techniques, he offered them orientation, stirred their attention, created suspense, and cross-referenced text and images."21 Writing in the tradition of physico-theology, ${ }^{22}$ Gottlieb Tobias Wilhelm saw nature as a manifestation of the divine plan of creation in which every living being had its fixed place and specific function. The Conversations about Man are also marked by the Enlightenment's optimistic view of human progress and the capacity of human beings to achieve perfection, propagating values like reason, tolerance, and humanity. Pfeuffer summarizes her reading of the books as follows:

\begin{abstract}
Humanity's common descent from a single pair, which Wilhelm argued for on the basis of the biblical story of creation as well as contemporary theories by the anthropologist Johann Friedrich Blumenbach (1752-1840), provided the foundation for [. . .] the equality of all peoples and individuals. On this footing, Wilhelm argued passionately in his Conversations about Man against the discrimination of Jews; for equal rights for women; against the exploitation of workers and soldiers in European and overseas factories, plantations, and armies; and against serfdom. His extensive portrait of the fate of negro [sic] slaves was an unequivocal statement in the contemporary debate about the abolition of the slave trade and an uncompromising plea against the misanthropy and greed of European colonizers. ${ }^{23}$
\end{abstract}

As the following analysis will show, however, Pfeuffer is overstating her case here, and her assessment of Wilhelm's position is somewhat one-dimensional. While it is true that the Augsburg pastor regarded Africans as being entitled to human rights and called them "brethren" in a Christian sense, he simultaneously adhered to contemporary concepts of stages of human civilization in which Europeans invariably occupied the highest stage. ${ }^{24}$ The peoples of Europe deserved preeminence for aesthetic

19 Pfeuffer, “Gottlieb Tobias Wilhelm,” 261-266, 269-271 (quote on page 266).

20 Pfeuffer, "Gottlieb Tobias Wilhelm," 271-272.

21 Pfeuffer, “Gottlieb Tobias Wilhelm,” 267.

22 Cf. Paul Michel, Physikotheologie - Ursprünge, Leistung und Niedergang einer Denkform (Zurich: Editions à la Carte, 2008); Anne-Charlott Trepp, Von der Glückseligkeit alles zu wissen: Die Erforschung der Natur als religiöse Praxis in der Frühen Neuzeit (Frankfurt: Campus, 2009).

23 Pfeuffer, "Gottlieb Tobias Wilhelm," 268-269.

24 Such views were prominently articulated by Scottish Enlightenment thinkers during the second half of the eighteenth century. Cf. Christopher J. Berry, Social Theory of the Scottish Enlightenment (Edinburgh: Edinburgh University Press, 1997), 93-99; Aaron Garrett, “Anthropology: The 'Original' of Human Nature," in The Cambridge Companion to the Scottish Enlightenment, ed. Alexander Broadie (Cambridge: Cambridge University Press, 2003), 79-93. On the reception of the Scottish 
as well as intellectual reasons: His readers would marvel, Wilhelm claimed, at the distance separating "the dwarf-like Lapp from the gigantic Patagonian; the black African with his flat face and woolly hair from the European with his regular features, white skin, and beautiful hair; the disgusting Hottentot from the cleanly Hollander; the dumb Huron and beastly Firelander from Kant and Herder."25 The Protestant clergyman apparently saw no contradiction between his commitment to the brotherhood of all men and his equally firm belief in distinctions between individuals and peoples. We may also add that he considered the sexes to be clearly distinguished in terms of different faculties and endowments; distinctiveness rather than equality characterized the relationship between men and women in his Conversations. ${ }^{26}$

It remains unclear whether Wilhelm was aware of Augsburg's involvement in the Atlantic slave trade and New World slavery ${ }^{27}$ - either during the city's "golden age" in the sixteenth century, when the Welser Company had been involved in the shipping of more than 4,000 slaves to America, ${ }^{28}$ or in recent decades. The Protestant merchant and banker Christian von Münch (1690-1757), for example, had purchased land in the North American colony of Georgia in 1750, presumably intending to establish a plantation there. Although the land was duly surveyed, Münch seems to have eventually abandoned his plans. ${ }^{29}$ During Wilhelm's own time, the city's leading Catholic bankers, the brothers Joseph Anton (1730-1795) and Peter Paul von Obwexer (1739-1817), traded with the Caribbean. Their representative on the island of Curaçao supplied textiles and other goods to French and Spanish plantation colonies and was also involved in slave trading

Enlightenment in Germany, see Fania Oz-Salzberger, Translating the Environment: Scottish Civic Discourse in Eighteenth-Century Germany (Oxford: Clarendon Press, 1995).

25 Wilhelm, Unterhaltungen über den Menschen, 1: 161. The references to "Lapps," "Patagonians," and "Hottentots" may reflect the influence of Linnaeus, who had classified these very peoples as a separate variety of the human species, which he termed "monsters," in the first edition of his Systema naturae in 1735: cf. Reimann, Entstehung des wissenschaftlichen Rassismus, 98.

26 Wilhelm, Unterhaltungen über den Menschen, 1: 2: "Power and majesty emanate from man, grace and loveliness from woman; together these [features] bring forth a proper mixture of seriousness and compassion, sternness and goodness to their common task of ruling over the world. Fully conscious of his strength and dignity, man strides forward, free and determined; his glance commands respect, whereas the softer, smiling glance of woman, who needs support to lean on, demands love."

27 For the following, cf. Mark Häberlein, "Augsburger Handelshäuser und die Neue Welt: Interessen und Initiativen im atlantischen Raum (16.-18. Jahrhundert)," in Augsburg und Amerika: Aneignungen und globale Verflechtungen in einer Stadt, ed. Philipp Gassert, Günther Kronenbitter, Stefan Paulus, and Wolfgang E.J. Weber (Augsburg: Wissner, 2014), 19-38.

28 Mark Häberlein, Aufbruch ins globale Zeitalter: Die Handelswelt der Fugger und Welser (Darmstadt: Theiss, 2016), 128-130.

29 George Fenwick Jones, The Georgia Dutch: From the Rhine and Danube to the Savannah, 1733-1783 (Athens: University of Georgia Press, 1992), 139, 146-147. 
on a small scale. ${ }^{30}$ But regardless of whether he was aware of these activities or not, Wilhelm clearly viewed the slave trade and slavery as general facets of the human condition rather than as specific local or regional phenomena.

\section{Africans in Gottlieb Tobias Wilhelm's Conversations}

For Wilhelm - as for numerous authors before him - the most distinctive feature of West Africans was the dark color of their skin. ${ }^{31}$ The Augsburg pastor was familiar with the contemporary learned theories on the origins of different skin colors, but he viewed them in a critical light and commented on them in ironic terms: While some authorities claimed that "negroes" had a blackish brain, he wrote, others believed that their blood was darker or that sulfur and mercury particles affected skin color. It was surprising, Wilhelm added, that scholars could have disagreed on the color of "negro blood" for so long given that the Europeans had had ample opportunities to see it long before the Dutch physician Peter Camper (1722-1789) dissected black bodies and found that their brains and blood resembled those of whites. ${ }^{32}$ Wilhelm disagreed with those who regarded black skin color to be a mark of divine disfavor or claimed that God had punished Cain and Ham with blackness for their sins: "So deeply rooted was this delusion that the black color represented something displeasing God, something ugly, that painters dipped their brushes into the negro's color to depict Satan. Who will therefore blame the negro if he - and we might say with better reason - imagines Satan being white, and if he believes like the unhappy American that God has marked certain maniacs with white color?"33

30 Mark Häberlein and Michaela Schmölz-Häberlein, Die Erben der Welser. Der Karibikhandel der Augsburger Firma Obwexer im Zeitalter der Revolutionen (Augsburg: Wissner, 1995).

31 Cf. Walter Demel, "Wie die Chinesen gelb wurden. Ein Beitrag zur Frühgeschichte der Rassentheorien,” Historische Zeitschrift 255 (1992): 625-666; Paul Münch, "Wie aus Menschen Weiße, Schwarze, Gelbe und Rote wurden: Zur Geschichte der rassistischen Ausgrenzung über die Hautfarbe," Essener Unikate 6/7 (1995): 86-97; Renato G. Mazzolini, "Skin Color and the Origin of Physical Anthropology (1640-1850)," in Reproduction, Race, and Gender in Philosophy and the Early Life Sciences, ed. Susanne Lettow (Albany: SUNY Press, 2014), 131-162; Francisco Bethencourt, Racisms: From the Crusades to the Twentieth Century (Princeton: Princeton University Press, 2014), passim.

32 Here Wilhelm refers to Peter Camper's lecture Redevoering over de oorsprong en de kleur der zwarten (1764), in which the Dutch scholar tried to dispel common misperceptions about fundamental differences between whites and blacks. The lecture was subsequently translated into German. Peter Camper, "Rede über den Ursprung und die Farbe der Schwarzen gehalten in Gröningen auf der anatomischen Schaubühne den 14. November 1764," in Camper, Kleinere Schriften die Arzney und Wundarzneyenzunft und fürnehmlich die Naturgeschichte betreffend, vol. 1/1, trans. J.F.M. Herbell (Leipzig: Siegfried Lebrecht Crusius, 1784), 24-49; cf. Reimann, Entstehung des wissenschaftlichen Rassismus, 160-161, 167-168.

33 Wilhelm, Unterhaltungen über den Menschen, 1: 163-164. On the early modern debate on this issue, see Mazzolini, “Skin Color," 140-142. 
Although he distanced himself from racial theories that he deemed absurd, Wilhelm had no doubt that different human races existed despite their close relationship and common descent, and that they could be distinguished according to their physical characteristics. Like Kant before him, Wilhelm referred to the principle of heredity to support this claim: ${ }^{34}$ Whites and blacks were neither different species nor varieties, as they could produce common offspring - "but they are of different races, as Moorish parents always have black [children], and white parents white children." 35

To explain these differences, he resorted to a moderate version of climate theory, which many eighteenth-century authors embraced in one form or another: ${ }^{36}$ While Montesquieu (1689-1755) and Jean-Baptiste Dubos (1670-1742) may have gone too far in ascribing all human differences - including religion, political constitution, and progress in the sciences - to the influence of different climates, Claude Adrien Helvétius (1715-1771) apparently leaned too far towards the other extreme with his denial of all external influences on physical and intellectual development. A middle ground between these extremes seemed most appropriate to Wilhelm: ${ }^{37}$ Apart from climate and geographical location, he believed that customs, lifestyles, food, lodging, material circumstances, and hygiene had a measurable impact on skin color. ${ }^{38}$ This was all the more important since as a Protestant clergyman, he clung to the biblical belief in monogenesis, i.e. the common origin of all human "races."39

Like climate theory, most racial theories debated in the years around 1800 appeared highly problematic. Explicitly referring to Carolus Linnaeus (1707-1778), Oliver Goldsmith (1728-1774), Johann Christian Polycarp Erxleben (1744-1777), John Hunter (1728-1793), Immanuel Kant, Bernard Germain Lacépède (1756-1825), and Johann Friedrich Blumenbach (1752-1840), ${ }^{40}$ Wilhelm states:

Men of merit have gone to great lengths to define human race according to certain characteristic differences and specify their boundaries. Alas, how great are the difficulties of this undertaking! The manifold shadings and the frequent mixing of the races, the innumerable fine gradations of all main races, the numerous, often inconceivable reasons that brought them about, the gaps in the geography and ethnography of ancient times, and especially the uncertainty which characteristics racial differences should be based on - whether color, body,

34 Concerning Kant, cf. Reimann, Entstehung des wissenschaftlichen Rassismus, 174-175.

35 Wilhelm, Unterhaltungen über den Menschen, 1: 196-197.

36 Cf. Gonthier-Louis Fink, "Von Winckelmann bis Herder: Die deutsche Klimatheorie in europäischer Perspektive," in Johann Gottfried Herder 1744-1803, ed. Gerhard Sauder (Hamburg: Meiner, 1987), 156-176; David Allan Harvey, The French Enlightenment and its Others: The Mandarin, the Savage, and the Invention of the Human Sciences (New York: Palgrave-Macmillan, 2012), 136-153.

37 Wilhelm, Unterhaltungen über den Menschen, 1: 183-184.

38 Wilhelm, Unterhaltungen über den Menschen, 1:164-165.

39 Wilhelm, Unterhaltungen über den Menschen, 1:136-138.

40 Wilhelm, Unterhaltungen über den Menschen, 1:200-205. Most of these racial theories are discussed in Reimann, Entstehung des wissenschaftlichen Rassismus, 94-100 (Linnaeus), 122-125 (Goldsmith), 168-182 (Kant), 201-221 (Blumenbach), 229-233 (Hunter). 
growth of hair, cranium, or something else -, the doubtfulness whether some feature is inherited or not; these and various other considerations make it exceedingly difficult to achieve certain progress in this question, which is so important for the history of man. ${ }^{41}$

Although he considered a distinction between five "main races" (Hauptracen), numerous "shadings" (Schattirungen) between them as well as different stages of human civilization plausible, ${ }^{42}$ Wilhelm was convinced that Africans were endowed with remarkable intellectual faculties. He also believed that they were able to improve themselves in accordance with the Enlightenment principles of human progress and perfectibility and could eventually prove their equality with Europeans, thus implying that they were unequal as a result of contemporary circumstances. Contrary to widespread scholarly belief, Wilhelm argued, there was no such thing as inherent racial superiority or inferiority. In a passage seeming to echo defendants of slavery and racial inequality like Christoph Meiners, he writes:

Philosophers still speak of negroes as if they were obviously a worse race than whites and stood infinitely far below them with regard to their intellect and heart. Yet they keep forgetting the difference between degeneration (Ausartung) and original depravity. One may concede the callousness, slackness, stupidity, and malignancy of negroes; [one may also] concede that it might be dangerous to manumit them all at once, especially in places where the many injustices which they had to suffer might prompt them to constantly plot for revenge; and yet one may assert their capability for culture (Culturfähigkeit). ${ }^{43}$

While refuting contemporary racial theories, Wilhelm thus simultaneously supported notions of racial inequality. He deemed it appropriate to include an extensive comment on the inhabitants of West Africa, as their fate appeared especially pertinent to the subject of his work. The African continent was larger than Europe, after all, and its population was still enormous despite having lost around 40 million healthy young people within a period of 250 years through the Atlantic slave trade - whose volume Wilhelm, like many contemporaries, wildly exaggerated. ${ }^{44}$ While the anatomy of Africans was distinct in certain respects, these were hardly substantial enough to "refuse the negro the designation of brother": Since their alleged intellectual inferiority to Europeans was unproven and evidence of their immunity to moral improvement, virtue, magnanimity, and ingeniousness was lacking, Wilhelm felt justified in calling their general treatment barbarous, inhuman, and a gross violation of the "holy rights of mankind." 45

41 Wilhelm, Unterhaltungen über den Menschen, 1: 198.

42 Wilhelm, Unterhaltungen über den Menschen, 1:205. Both Blumenbach and the Swiss scholar Christoph Girtanner (1760-1800) had proposed classifications of humanity into five main "races" or “varieties”; cf. Reimann, Entstehung des wissenschaftlichen Rassismus, 196-197, 209-210.

43 Wilhelm, Unterhaltungen über den Menschen, 1: 311.

44 Wilhelm, Unterhaltungen über den Menschen, 1: 311. The most reliable estimate, provided by the Trans-Atlantic Slave Trade Database, is about 12.5 million slaves transported during the entire period from 1501 to 1875: https://www.slavevoyages.org/assessment/estimates (accessed June 1, 2019).

45 Wilhelm, Unterhaltungen über den Menschen, 1: 312-313. 
In order to substantiate these claims, Wilhelm offered historical and contemporary examples, quoting passages from travel narratives about Africa that praised the talents and accomplishments of peoples and individuals. In the literature he consulted, Wilhelm found ample proof of Africans' achievements in agriculture, the arts and crafts, urban architecture and design, as well as evidence for character traits like familial love (Familienliebe), hospitality, and gallantry (Edelmuth). ${ }^{46}$

It should not be overlooked, however, that the yardstick used by the author of the Conversations to measure the abilities and accomplishments of West Africans was the degree to which they had adopted "European culture." In the Congo basin, for example, many already spoke French, and the dishes at the ruler's dining table were said to be excellent. The reports by European travelers also provided numerous "samples of artistic ingenuity" (Proben eines denkenden Kunstfleißes) like well-organized iron-smelting works, skillful weavers, and diligent wage workers. ${ }^{47}$ The explorer Mungo Park (1771-1806) had been served beer that he compared to the best English brews, and James Bruce (1730-1794) had admired the female favorite of the "negro king" Barrah, whose physical attractiveness matched the skillfulness of her polite conversation in French, English, or Portuguese as well as the elegance of her wardrobe and furnishings, which rivalled those of "the first lady [sic] in Europe."48

On the other hand, Wilhelm also found drastic examples of African "savagery" and barbarity in his sources: He cited the "truly talented, but cruel" seventeenthcentury Angolan princess Xinga as a shocking example of mercilessness. Her band of followers allegedly consumed human flesh on a regular basis, while Xinga herself slaughtered several hapless victims and drank their blood before every military campaign. These horrors were graphically depicted in the accompanying illustration (Fig. 9.3). ${ }^{49}$ Wilhelm also ascribed character traits like vanity, cruelty, and callousness to Africans. ${ }^{50}$

46 Wilhelm, Unterhaltungen über den Menschen, 1: 315-318, 323-324.

47 Wilhelm seems to have taken this information from Zimmermann, Taschenbuch der Reisen, 1: 35-36.

48 Wilhelm, Unterhaltungen über den Menschen, 1: 318-319. A German translation of Park's travel narrative had been published a few years earlier: Mungo Park, Reisen im Innern von Afrika auf Veranstaltung der afrikanischen Gesellschaft in den Jahren 1795 bis 1797 (Berlin and Hamburg: n.p., 1800). The drink that supposedly tasted as good as English beer is mentioned on page 35, but Wilhelm probably borrowed the passage from Zimmermann, Taschenbuch der Reisen, 1: 36. For the German translation of Bruce's travelogue, see James Bruce, Reisen zur Entdeckung der Quellen des Nils, trans. Johann Jacob Volkmann, 5 vols. (Leipzig: Weidmann, 1790-91); a digital version is available from the University and State Library Münster at urn:nbn:de:hbz:6:1-12691.

49 Wilhelm, Unterhaltungen über den Menschen, 1: 96. The story of Xinga, which was transmitted through works like Olfert Dapper, Umbständliche und Eigentliche Beschreibung von Africa, und denen darzu gehörigen Königreichen und Landschaften [. . .] (Amsterdam: Jacob von Ments, 1670), 296-298, was adapted by Zimmermann, Taschenbuch der Reisen, 1: 68-74.

50 Wilhelm, Unterhaltungen über den Menschen, 1: 334-335. 


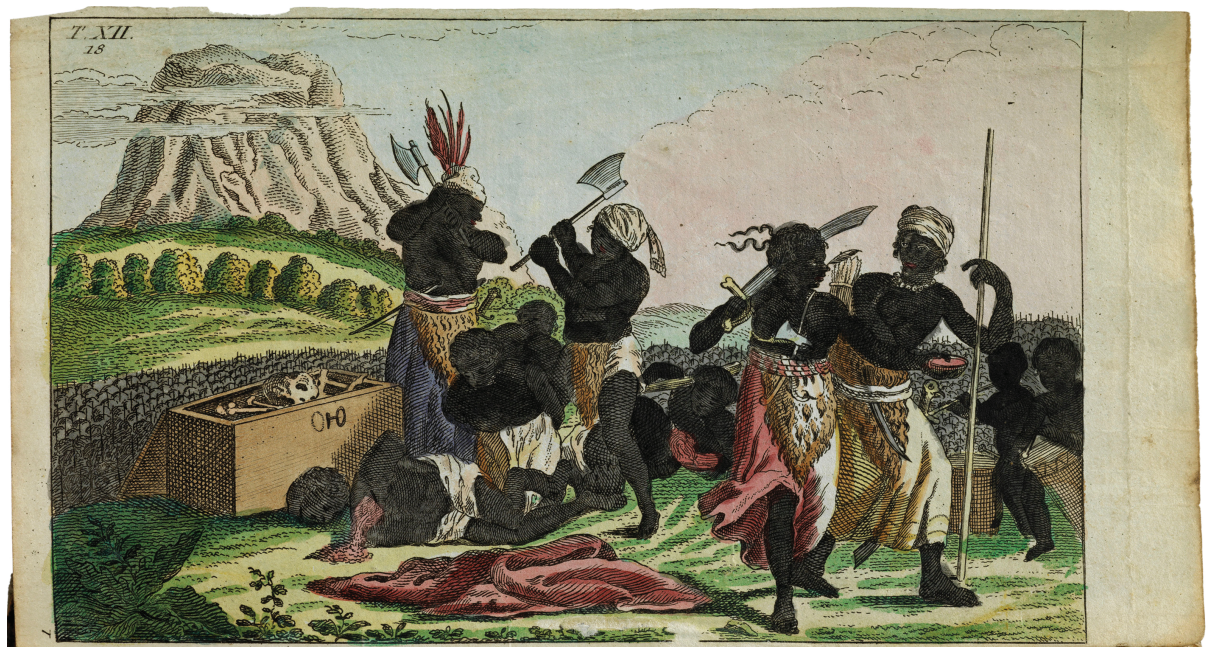

Fig. 9.3: The Angolan princess Xinga and her followers as examples of "African cruelty." Gottlieb Tobias Wilhelm, Unterhaltungen über den Menschen (Augsburg: Martin Engelbrecht, 1804), Table XII.

Wilhelm believed that Africans could find much better conditions and opportunities for developing their intellectual and moral potential in Europe and America than on their native continent - an argument likewise used by defendants of slavery. ${ }^{51}$ Here, too, refuting contemporary racial theories did not mean that Wilhelm's observations were devoid of racist notions. He marveled at "the negroes' obvious refinement (Veredlung) by means of their transplantation to the West Indies" and thought it "a sublime idea that even humans who occupy the lowest rank may be perfected in mind and body merely by their transfer to other regions." 52 Pertinent examples were "the negro captain [Leonard] Parkinson," a leader of runaway slaves (maroons) who had established a "free negro republic" in the Jamaican interior, ${ }^{53}$ and above all the leader of the Haitian Revolution, Francois-Dominique Toussaint Louverture (c. 1743-1803), who in Wilhelm's view was endowed with superhuman qualities:

Who does not marvel, in our wonderful times, at the miraculous appearance of one Toussaint Louverture. An eyewitness says of him that he merits the respect of all polite peoples - as a man, by his consideration for the unfortunate; as a governor, by his wisdom; as a general, by the most ingenious maneuvers; and [this witness adds] that his kindness of heart, which he emanates despite his blackness and his fifty-five years of age, win over each and every heart [. . .]. Has he not demonstrated the feasibility of establishing a negro state governed according to European ideas? Has destiny ever articulated its will regarding the future refinement of blacks more clearly

51 Cf. Meiners, "Historische Nachrichten," 663-664.

52 Wilhelm, Unterhaltungen über den Menschen, 1: 314.

53 Wilhelm, Unterhaltungen über den Menschen, 1: 320-321. 
than through Toussaint; and would he not be universally considered a great man if he had been more fortunate? ${ }^{54}$

Besides underscoring the importance of the Haitian Revolution as a media event that German readers could follow in numerous journal articles, pamphlets, tracts, eyewitness accounts, and literary works, this passage also shows that Gottlieb Tobias Wilhelm primarily relied on authors who saw the events in a favorable light and viewed Toussaint as a great leader. ${ }^{55}$ Moreover, the phrasing emphasizes that Toussaint had envisioned a republic "governed according to European ideas." Once again, Europe thus represented the benchmark against which an African's achievements were measured.

Another African whom Wilhelm considered an exceptional "representative of the Ethiopian [sic] race” was the Reformed preacher Jacobus E. J. Capitein (c. 1717-1747), who had been purchased on the Gold Coast and taken to Holland as a child. Growing up in a West India trader's household in The Hague, Jacobus had received a thorough classical education and studied theology at the University of Leiden before returning as a missionary to Elmina, the major Dutch slave trading post on the Gold Coast. ${ }^{56}$ Wilhelm considered Capitein's sermons and other writings in Latin and Dutch to "betray extraordinary talent." 57 Graman Quassie (Kwasimukamba), portrayed by John Gabriel Stedman in his narrative of Suriname as a former slave who had gained renown for discovering a medicinal root and subsequently been honored by the Prince of Orange in Holland, was likewise praised by Wilhelm for his excellent character. Quassie's portrait was copied from Stedman's work for the Conversations (cf. Fig. 9.4). ${ }^{58}$

Wilhelm underscored his point that Africans allegedly realized their full potential in Europe or America rather than on their continent of origin with two further examples: Firstly, the Fula speaker Jallo had been captured and sent to England, "where his reasonable behavior, but above all his memory and understanding created a general sensation." Wilhelm claimed that Jallo had written down the Coran from memory three times, and that he had completely taken apart and reassembled

54 Wilhelm, Unterhaltungen über den Menschen, 1: 321.

55 Cf. Schüller, Die deutsche Rezeption, esp. 94-114, 171-186; Iwan Michelangelo d'Aprile, Die Erfindung der Zeitgeschichte: Geschichtsschreibung und Journalismus zwischen Aufklärung und Vormärz (Berlin: Akademie Verlag, 2013), 155-168.

56 David Nii Anum Kpobi, Saga of a Slave: Jacobus Capitein of Holland and Elmina (Oxford: African Books Collective, 2002).

57 Wilhelm, Unterhaltungen über den Menschen, 1: 207-208.

58 Wilhelm, Unterhaltungen über den Menschen, 1: 321-322. Cf. Richard Price, “Kwasimukamba’s Gambit,” Bijdragen tot de taal-, land- en volkenkunde 135 (1979): 151-169; Allison Blakely, Blacks in the Dutch World: The Evolution of Racial Imagery (Bloomington: Indiana University Press, 1993), 253-256; Mark Häberlein, “Kulturelle Vermittler in der atlantischen Welt der Frühen Neuzeit," in Sprachgrenzen - Sprachkontakte - Kulturelle Vermittler. Kommunikation zwischen Europäern und Außereuropäern (16.-20. Jahrhundert), ed. Mark Häberlein and Alexander Keese (Stuttgart: Steiner, 2010), 177-201, esp. 191-194. 


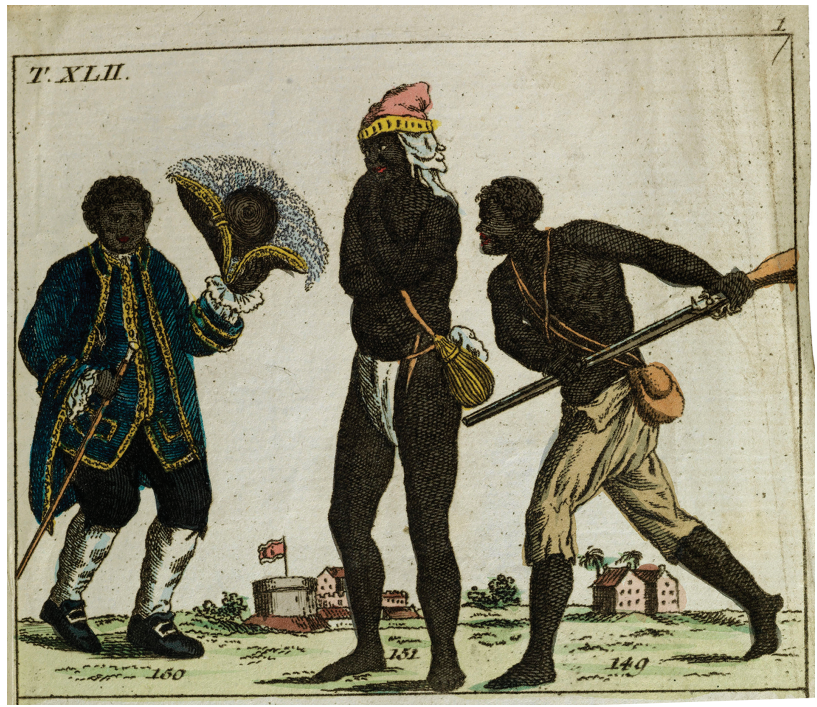

Fig. 9.4: The Afro-American healer Graman Quassie (Kwasimukamba), adapted from John Gabriel Stedman's Narrative of a Five Years Expedition against the Revolted Negroes of Surinam (1796). Gottlieb Tobias Wilhelm, Unterhaltungen über den Menschen (Augsburg: Martin Engelbrecht, 1804), Table XLII.

a watch and the model of a mill. Moreover, he had written an autobiography and appeared to possess considerable poetic talent. Lastly, an enslaved eight-year-old African girl had learned English within six months, then taken up Latin and published skillful poems before she turned twelve. ${ }^{59}$ Like the abbé Henri Grégoire in his famous work De la littératre des Nègres first published in 1808, Wilhelm therefore regarded the autobiographical and literary works of blacks as proof of the intellectual capacity and perfectibility of human nature. ${ }^{60}$

\section{The Slave Trade in Wilhelm's Conversations}

On the whole, Wilhelm stated, there was hardly any field of science "that did not include some famous negroes.” While he found it remarkable that many West Africans realized their full intellectual potential only during their stays in foreign

59 Wilhelm, Unterhaltungen über den Menschen, 319-320. Wilhelm apparently copied these examples from Zimmermann, Taschenbuch der Reisen, 1: 39-43. Zimmermann identified the slave girl as Phillis Wheatley (ca. 1753-1804) and rendered a stanza from her poem "Thoughts on Imagination" in the English original as well as in a German translation (Zimmermann, Taschenbuch der Reisen, 1: 42-43). Cf. Vincent Carretta, Phillis Wheatley: Biography of a Genius in Bondage (Athens: University of Georgia Press, 2011).

60 Cf. Lüsebrink, "Wissen und außereuropäische Erfahrung,” 634. 
countries, his examples nevertheless provided evidence that their capacities were equal to those of whites. ${ }^{61}$ The crucial fact remained that Africans possessed these qualities and were capable of self-perfection. It was from this perspective that Wilhelm passionately attacked the Atlantic slave trade:

And is it conceivable that all these human beings are of a worse nature than the rest of mankind? One takes license to capture and sell them like animals, and more than two and a half million negroes are living in the western hemisphere, far from their ancestral land, in a sometimes more, sometimes less oppressive state of slavery, which costs Africa 255,000 healthy people each year! England, which derives the largest profit from this trade but may also bear most of the blame of the friends of mankind, not only supplies its own colonies but those of other nations as well with these people, whose mortality on account of their transplanting and harsh treatment is horrible, and which [colonies] consequently require new recruits for precisely this reason. ${ }^{62}$

Wilhelm conceded that the inner-African slave trade had existed long before the arrival of the Europeans - an aspect that Matthias Christian Sprengel had likewise emphasized in his 1779 lecture on the origins of slave trafficking ${ }^{63}$ - and admitted that the wars between various ethnic groups in West Africa as well as the greed of "negro princes" (Negerfürsten) for liquor and other European goods stimulated the trade. But this by no means absolved the European slave traders of their responsibility in his eyes: "[W]ho gave them this terrible gift [brandy] and guns to boot? Who diligently inebriated even the better negro princes in order to goad them to rob and sell their subjects in their state of intoxication? Who provided such a strong enticement to this detrimental sort of human trafficking through foreign goods? Who prompted the cruelest wars merely for the sale of captives? Who else but the Europeans?"64

This series of rhetorical questions also demonstrates that Wilhelm, a clergyman by profession, was heavily emotionalizing his topic, thereby adopting a technique common among British abolitionists. ${ }^{65}$ Rather than providing a sober, factual account, Wilhelm clearly aimed to deliver a forceful and passionate portrait of a deplorable business:

Amidst a thousand tears of separation, intermingled with inhuman beatings and the roll of the drums, which is designed to make the sighs of the unfortunate victims inaudible, they are carried away to the colonies, [. . .]. There is no crime that the slave trader does not commit to complete his cargo in due time. [. . . ] The brokers who collect them in the countryside and deliver them to the slave traders tie the purchased slaves with twisted leather bands in groups of

\footnotetext{
61 Wilhelm, Unterhaltungen über den Menschen, 1: 320. Wilhelm shared these convictions with Zimmermann, Taschenbuch der Reisen, 1: 45-46.

62 Wilhelm, Unterhaltungen über den Menschen, 1: 325.

63 Sprengel, Vom Ursprung des Negerhandels, 5-20.

64 Wilhelm, Unterhaltungen über den Menschen, 1: 326-327.

65 Cf. Leo d'Anjou, Social Movements and Cultural Change: The First Abolition Campaign Revisited (New York: De Gruyter, 1996), 190, 223-224; Brycchan Carry, British Abolitionism and the Rhetoric of Sensibility: Writing, Sentiment, and Slavery 1760-1807 (London: Macmillan, 2005).
} 
four and bind them by night. The closer the unfortunate [men and women] from the country's interior approach the sea (which they fear very much), the more they fall into a melancholy state, and the sight of white people makes a horrible impression on them since they believe the devil to be white and are under the delusion that the whites eat negroes. Now the slave ship takes on its cargo. Alas, who can bear the sight without a bleeding heart! Thus more than 600 slaves lie tightly packed together in this abominable, stinking abyss of the Liverpool ship, and a diabolical economy knows how to fill the space with as many humans as possible. [. . .] Oh, it is a veritable cave of death, full of pestilential vapors! Imagine the sighs of the unfortunate, the anger of the desperate, the rattle of the dying, the decay of the (thank God!) expired, to whom the survivors often remain shackled for an extensive period - will anyone be surprised to find that some slave ships lose more than half of their cargo ${ }^{66}$

In equally drastic terms, Wilhelm castigated the slave traders for their cruel treatment of their captive cargo and the unbearable conditions aboard the slave ships. Basing his account mostly on Eberhard August Wilhelm von Zimmermann's digest of travel literature (who in turn relied on abolitionist writers like Olaudah Equiano and Thomas Clarkson) ${ }^{67}$ and reproducing one of the iconic images of a slave ship (Fig. 9.5), ${ }^{68}$ he graphically evoked the horrors of the Middle Passage with the same emotionally charged rhetoric:

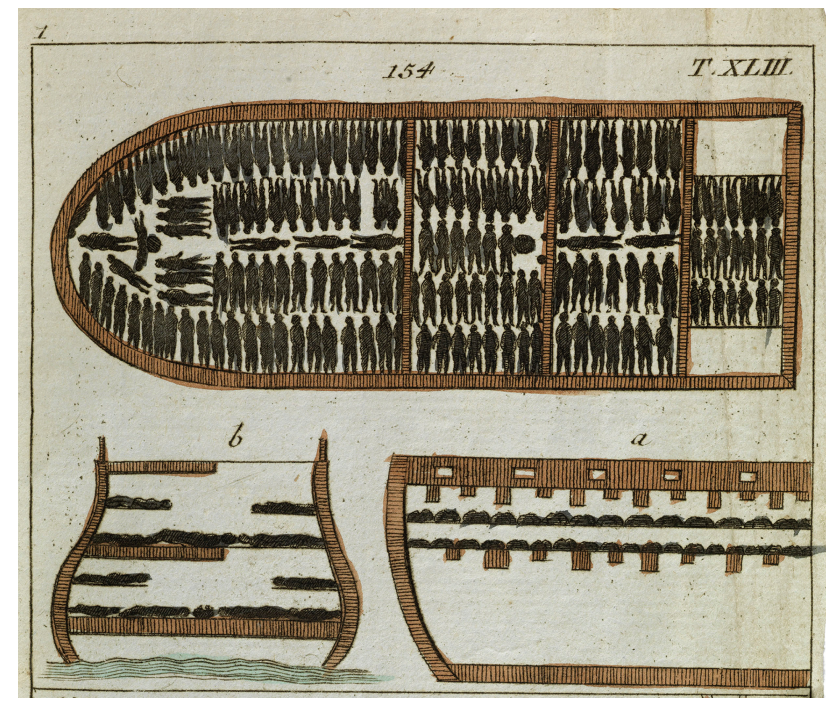

Fig. 9.5: Plan of a slave ship. Gottlieb Tobias Wilhelm, Unterhaltungen über den Menschen (Augsburg: Martin Engelbrecht, 1804), Table XLIII.

66 Wilhelm, Unterhaltungen über den Menschen, 1: 327-329.

67 Cf. Zimmermann, Taschenbuch der Reisen, 1: 110-138.

68 Cf. Marcus Rediker, The Slave Ship: A Human History (New York: Viking, 2007), 312, 315-316. 


\begin{abstract}
Usually the blacks refuse to take food during the first few days. Yet their tormentors have no difficulty finding a remedy. They bring up the women and children, and whip them with a terrible knotted whiplash, of which every white man on the slave ship has one. It is touching how the wives and children beg the husband and father amidst these lashes to hold firm in his commitment to starving, and prefer death over slavery. Yet it is even more touching that the sufferings of his beloved ones are the only thing that moves him [the slave] to finally accept food. But when a storm eventually makes it necessary to close all vents, and when a calm causes rations to become scarce, and the poor negroes are thrown overboard alive, or killed by poison - but let us hurry away from this most disgusting part of human history, and follow the poor negro to the destination of his fate. ${ }^{69}$
\end{abstract}

With these words, Wilhelm drew the attention of his readers to slavery in the Americas. Shortly before the ships approached their ports of destination, he explains, the slaves received better treatment, including being washed and rubbed in palm oil - but merely to allow them to be sold for a higher price. Whereas some slave traders let their clients choose from their offering, others sold their slaves at auction. According to Wilhelm, adult men were usually sold for fifty pounds sterling, while women fetched forty-nine and youths forty-six pounds; skilled workers could be worth up to one thousand pounds. The slave's body was subsequently branded with the name of his or her master. ${ }^{70}$ This passage is an abridgement of the second volume of Zimmermann's Pocketbook of Travels (1802), which was entirely devoted to the West Indies. ${ }^{71}$

Wilhelm also claimed that the price of a slave depended on whether he was a "Kormentin" (a slave sold by an African ruler), a "Papa” (war captive), or a "Luango" (criminal). ${ }^{72}$ This statement was obviously based on a defective information chain, for when eighteenth-century travel writers like the physicians Philippe Fermin (1720-1790) and Paul Erdmann Isert (1756-1789) mentioned these categories of slaves, they correctly identified them as referring to specific regions of origin. ${ }^{73}$ An article in a popular magazine purported the identification as princely slaves, captives, and criminals in 1795 , however, and it subsequently found its way into Wilhelm's work. ${ }^{74}$

Apart from his brief remarks on slave auctions and prices, Wilhelm provided no account of the organization of plantations, hierarchies among slaves, living and working conditions, or the colonial economies - information he could have found in Zimmermann's Pocketbook, from which he obviously copied much of his account of the slave trade. ${ }^{75}$ Instead, he restricted himself to illustrating the slaves' fate by

\footnotetext{
69 Rediker, The Slave Ship, 329.

70 Wilhelm, Unterhaltungen über den Menschen, 1: 329-330.

71 Zimmermann, Taschenbuch der Reisen, 2: 63-69.

72 Wilhelm, Unterhaltungen über den Menschen, 1: 330.

73 Philippe Fermin, Ausführliche historisch-physikalische Beschreibung der Kolonie Surinam, 2 vols. (Berlin: Joachim Pauli, 1775), 1:101; Paul Erdmann Isert, Reise nach Guinea in Afrika und Westindien, Bibliothek der neuesten Reisebeschreibungen 8 (Frankfurt: Weigel \& Schneider, 1790), 338.

74 [anonymous article] “Neger Sklaven,” Wahrheit und Dichtung 1 (1795): 7-8.

75 Zimmermann, Taschenbuch der Reisen, 2: 69-81.
} 
recounting individual anecdotes from travel literature, especially from Stedman's narrative of Suriname, thereby suggesting that he was less interested in social and political conditions in the colonies than in moral lessons. He evoked scenes of a crying female slave going to work with her children; of an old, worn-out slave devouring a piece of rotting meat; of overseers mercilessly whipping blacks for minor offenses; of fleeing slaves chased by bloodhounds; and of draconic punishments like the cutting of ears and hamstrings or the amputation of limbs. "In Suriname," Wilhelm writes, "the white planter's boy punches the old negress with his fists because she has slightly touched his powdered hair while putting down the bowl; and a cook stabbed himself at the hearth simply for spoiling a ragout and being certain of the most inhuman punishment. In the same place a person fastened a negro to a dog's cabin with a chain and spiky collar, and forced him to bark whenever somebody was entering the courtyard."76 It was little wonder, Wilhelm thought, that so many runaway slaves joined maroon communities and fought their former oppressors in merciless wars, or rose in bloody rebellions on the islands of Jamaica and Saint-Domingue. ${ }^{77}$ He also deemed it "remarkable" that "white women, on average, are much harder on the negroes than the men" - yet another observation taken from Zimmermann's Pocketbook of Travels: ${ }^{78}$

\begin{abstract}
Eyewitnesses saw them handle the mangling whip, drip sealing wax on the back [of slaves], slit nasal wings, apply thumbscrews. A certain Madame S. in Suriname - why was her name, out of inappropriate consideration, not spelled out more clearly to expose her to the contempt of the entire world? - went to her plantation by boat together with a negress who was nursing an infant at her breast. The infant was crying. I will calm it, the white beast says quite naturally, and dips it into the water by the feet until it drowns. The despairing mother wants to take her life and throws herself into the waves. She is picked up - and cruelly whipped. We ask our readers for forgiveness that we must hurt their sensibility with such scenes. But we have no choice. They must become familiar with human nature as a whole (Sie müßen den Menschen ganz kennen lernen). ${ }^{79}$
\end{abstract}

This final sentence sums up the author's intentions rather succinctly: His readers were to "become familiar with human nature as a whole." For this purpose, Wilhelm offered up a wide panorama of humans' physical and intellectual abilities as well as their character traits. And despite his deeply held conviction that man, as the crown of divine creation, was capable of perfecting his endowments and talents, the full picture necessarily had to include the scenes of cruelty and debasement

76 Wilhelm, Unterhaltungen über den Menschen, 1: 330-331.

77 Wilhelm, Unterhaltungen über den Menschen, 1: 332-333. Wilhelm relied on the accounts of the maroon wars and the Haitian Revolution in Zimmermann, Taschenbuch der Reisen, 2: 94-122.

78 Cf. Zimmermann, Taschenbuch der Reisen, 2: 82-85.

79 Wilhelm, Unterhaltungen über den Menschen, 1: 331-332. Here Wilhelm drew upon a passage from Stedman, Narrative of a Five Years' Expedition, 1: 343 that in turn is taken almost verbatim from Zimmermann, Taschenbuch der Reisen, 2: 85. Cf. also Gwilliam's remark that white women's "defining characteristic" in Stedman's narrative is "sadism." Gwilliam, “'Scenes of Horror, ," 658. 
generated by the slave trade and plantation slavery. As a deterring example of man's capacity for evil, Wilhelm placed the slave trade alongside famines caused by usury, the excesses during the radical phase of the French Revolution, and the futile causes of some European wars:

[W] hen the unfeeling slave trader tears the infant from its mother's breast and throws it away; when the cursed usurer in Bengal locks up his rice so that 30,000 Indians perish of hunger within a few weeks, or, like an unfeeling stone, causes an artificial dearness in order to snatch the crying poor's last farthing; when women in cultivated cities dance around jerking corpses with cannibalistic glee, and a well-educated people, in dumb terror, permits its noblest persons to be strangled [. . .]; when among the distinguished whites, war and peace may depend on a single glove, some drops of water, or the injured pride of a sole individual: How dare we justify the unfortunate negroes' bitter fate by their pride, their vanity, or their cruelty, and regard the inhuman deeds of slave traders and planters with any less revulsion? ${ }^{80}$

Once again, while Wilhelm's moral message is clear, his position on the (in)equality of the human "races" is still ambivalent: Although he rebukes the "whites" for various crimes and "inhuman deeds," Africans remain associated with negative character traits like "pride," "vanity," and "cruelty."

Writing on the eve of the abolition of the British slave trade in 1807, Gottlieb Tobias Wilhelm regarded the outlook for improving the slaves' circumstances as uncertain. He referred to the efforts of William Wilberforce (1759-1833), the spokesman of the British abolitionist movement in Parliament, mentioned that the Quakers were manumitting their slaves, and cited the establishment of a "free state for free negroes" in Sierra Leone. While these prospects delighted the "friends of mankind," hopes began to diminish again when a French fleet destroyed this "excellent institution" and the British Parliament - "the platform where, on other occasions, men spoke of human rights in such grandiloquent expressions" - seemed interested exclusively in the advantages associated with colonialism (Colonialvortheilen). For the sake of English humanity, however, Wilhelm did add that an institute for the education of young blacks had been set up in Clapham, Surrey. ${ }^{81}$

\footnotetext{
80 Wilhelm, Unterhaltungen über den Menschen, 1: 336-337. Wilhelm's comments on the usurers of Bengal and Europe were adaptations of Zimmermann, Taschenbuch der Reisen, 1: 143.

81 Wilhelm, Unterhaltungen über den Menschen, 333-334. Here Wilhelm once again summarized information from Zimmermann, Taschenbuch der Reisen, 1: 143-150. On the historical background, cf. Adam Hochschild, Bury the Chains: The British Struggle to Abolish Slavery (London: Macmillan, 2005); Christopher Leslie Brown, Moral Capital: Foundations of British Abolitionism (Chapel Hill: University of North Carolina Press, 2006); Anne Stott, Wilberforce: Family and Friends (New York and Oxford: Oxford University Press, 2012).
} 


\section{Conclusion}

The Protestant clergyman Gottlieb Tobias Wilhelm, author of a multi-volume popular work on natural history and anthropology, closely followed the intellectual debates of his time and quoted numerous philosophers, scientists, and travel writers. It is not always clear, however, whether he had actually consulted the original works or simply relied on other compilations. As we have seen, his accounts of Africans and the slave trade were frequently adapted from Eberhard August Wilhelm Zimmermann's digest of travel narratives and John Gabriel Stedman's account of Suriname. The Conversations about Man therefore provide an example of the information chains through which knowledge on West Africa and Atlantic slavery was disseminated in various media and reassembled in German encyclopedic and didactic works during the years around 1800.

Wilhelm's Conversations not only sought to instruct readers and transmit knowledge, however. The numerous episodes and examples, which were often detached from their original contexts, as well as the frequent references to the accompanying illustrations provided additional vividness and clarity. Moreover, Wilhelm employed a wide range of rhetorical devices to arouse his readers' compassion. The Augsburg pastor wanted to point out the accomplishments as well as the abominations humans were capable of. He considered the Atlantic slave trade and plantation slavery among the grossest crimes against humanity; and even though African traders and rulers bore some responsibility, Wilhelm entertained no doubt that Europeans were the main culprits.

Yet this article has also shown that Gottlieb Tobias Wilhelm's views on Africans, the Atlantic slave trade, and New World slavery were more ambivalent than Renate Pfeuffer was willing to concede in her pioneering study on the Augsburg pastor. While he castigated the evils of the Middle Passage and the cruel treatment of slaves in American plantation societies, Wilhelm also associated Africans with certain negative character traits and named African princes and traders as accomplices in the slave trade. Moreover, although he rejected contemporary racial theories, Wilhelm believed in the existence of racial distinctions, adhered to a moderate version of climate theory, and thought that Africans could realize their full human potential only in Europe and America. In these respects, Wilhelm's work was very much a product of its time. 


\section{References}

\section{Printed Sources}

Bruce, James. Reisen zur Entdeckung der Quellen des Nils. Translated by Johann Jacob Volkmann. 5 vols. Leipzig: Weidmann, 1790-1791.

Camper, Peter. "Rede über den Ursprung und die Farbe der Schwarzen gehalten in Gröningen auf der anatomischen Schaubühne den 14. November 1764." In Camper, Kleinere Schriften die Arzney und Wundarzneyenzunft und fürnehmlich die Naturgeschichte betreffend, 24-49. Vol. 1/1. Translated by J.F.M. Herbell. Leipzig: Siegfried Lebrecht Crusius, 1784.

Dapper, Olfert. Umbständliche und Eigentliche Beschreibung von Africa, und denen darzu gehörigen Königreichen und Landschaften [. . . .]. Amsterdam: Jacob von Ments, 1670.

"Etwas über des Herrn Hofrath Meiners Vertheidigung des Negerhandels, im Göttingischen historischen Magazin [. . .]." Beiträge zur Beruhigung und Aufklärung 2, no. 3 (1791): 642-659.

Fermin, Philippe. Ausführliche historisch-physikalische Beschreibung der Kolonie Surinam. Vol. 1. Berlin: Joachim Pauli, 1775.

Isert, Paul Erdmann. Reise nach Guinea in Afrika und Westindien. Frankfurt: Weigel \& Schneider, 1790.

Meiners, Christoph. "Ueber die Rechtmässigkeit des Negern-Handels." Göttingisches Historisches Magazin 2 (1788): 398-416.

Meiners, Christoph. "Über die Natur der Afrikanischen Neger, und die davon abhangende Befreyung, oder Einschränkung der Schwarzen." Göttingisches Historisches Magazin 6, no. 3 (1790): 385-456.

Meiners, Christoph. "Historische Nachrichten über die wahre Beschaffenheit des Sclaven-Handels, und die Knechtschaft der Neger in West-Indien." Göttingisches Historisches Magazin 6, no. 4 (1790): 645-679.

Meiners, Christoph. "Fortgesetzte Betrachtungen über Sclavenhandel und die Freilassung der Neger." Neues Göttingisches Historisches Magazin 2, no. 1 (1793): 1-58.

"Neger Sklaven." Wahrheit und Dichtung 1 (1795): 7-8.

Park, Mungo. Reisen im Innern von Afrika auf Veranstaltung der afrikanischen Gesellschaft in den Jahren 1795 bis 1797. Berlin: n.p., 1800.

Sartori, Franz, ed. Ueberlieferungen aus der Neuen Welt, oder die Staaten, Colonien und Völker jenseits des Meeres, der Schauplatz gewaltiger Ereignisse, das Augenmerk von ganz Europa [ . . . ]. Vol. 2. Brno: Joseph Georg Traßler, 1818.

Sell, Johann Jacob. Versuch einer Geschichte des Negersclavenhandels. Halle: Johann Jacob Gebauer, 1791.

Sprengel, Matthias Christian. Vom Ursprung des Negerhandels. Ein Antrittsprogramm. Halle: Johann Christian Hendel, 1779.

Sprengel, Matthias Christian, ed. Alex[ander] Falconbridges und Thomas Clarksons Bemerkungen über die gegenwärtige Beschaffenheit des Sclavenhandels und dessen politische Nachtheile für England. Leipzig: Weygand, 1790.

Stedman, John Gabriel. Narrative of a Five Years Expedition against the Revolted Negroes of Surinam, in Guiana, on the Wild Coast of South America: From the Year 1772, to 1777. 2 vols. London: J. Johnson, 1796.

Stedman, John Gabriel. Stedman's Nachrichten von Suriname und von seiner Expedition gegen die rebellischen Neger in dieser Kolonie in den Jahren 1772-1777. Ein Auszug aus dem Englischen Original, trans. C.W. Jakobs and F. Kies. Hamburg: Benjamin Gottlob Hoffmann, 1797. 
Wilhelm, Gottlieb Tobias. Unterhaltungen über den Menschen. 3 vols. Augsburg: Martin Engelbrecht, 1804-1806.

Zimmermann, Eberhard August Wilhelm von. Taschenbuch der Reisen oder unterhaltende Darstellung der Entdeckungen des 18. Jahrhunderts, in Rücksicht der Länder-, Menschen- und Productenkunde, vols. 1 and 2. Leipzig: Gerhard Fleischer d.J., 1802.

\section{Literature}

Berry, Christopher J. Social Theory of the Scottish Enlightenment. Edinburgh: Edinburgh University Press, 1997.

Bethencourt, Francisco. Racisms: From the Crusades to the Twentieth Century. Princeton: Princeton University Press, 2014.

Blakely, Allison. Blacks in the Dutch World: The Evolution of Racial Imagery. Bloomington: Indiana University Press, 1993.

Brown, Christopher Leslie. Moral Capital: Foundations of British Abolitionism. Chapel Hill: University of North Carolina Press, 2006.

Carretta, Vincent. Phillis Wheatley: Biography of a Genius in Bondage. Athens: University of Georgia Press, 2011.

Carry, Brycchan. British Abolitionism and the Rhetoric of Sensibility: Writing, Sentiment, and Slavery 1760-1807. London: Macmillan, 2005.

Chukwudi Eze, Emmanuel. "The Color of Reason: The Idea of 'Race' in Kant's Anthropology." In Anthropology and the German Enlightenment: Perspectives on Humanity, edited by Katherine M. Faull, 200-241. Lewisburg: Bucknell University Press, 1995.

D’Anjou, Leo. Social Movements and Cultural Change: The First Abolition Campaign Revisited. New York: De Gruyter, 1996.

D’Aprile, Iwan Michelangelo. Die Erfindung der Zeitgeschichte. Geschichtsschreibung und Journalismus zwischen Aufklärung und Vormärz. Berlin: Akademie Verlag, 2013.

Demel, Walter. "Wie die Chinesen gelb wurden. Ein Beitrag zur Frühgeschichte der Rassentheorien," Historische Zeitschrift 255 (1992): 625-666.

Eckert, Andreas. "Aufklärung, Sklaverei und Abolition." In Die Aufklärung und ihre Weltwirkung, edited by Wolfgang Hardtwig, 243-262. Göttingen: Vandenhoeck \& Ruprecht, 2010.

Eigen, Sara, and Larrimore, Mark, eds. The German Invention of Race. Albany: SUNY Press, 2006. Fendler, Ute, and Greilich, Susanne. "Afrika in deutschen und französischen Enzyklopädien des 18. Jahrhunderts." In Das Europa der Aufklärung und die außereuropäische koloniale Welt, edited by Hans-Jürgen Lüsebrink, 113-137. Göttingen: Wallstein, 2006.

Feuerstein-Herz, Petra. Der Elefant der Neuen Welt. Eberhard August Wilhelm von Zimmermann (1743-1815) und die Anfänge der Tiergeographie. Stuttgart: Deutscher Apotheker-Verlag, 2006.

Fink, Gonthier-Louis. "Von Winckelmann bis Herder: Die deutsche Klimatheorie in europäischer Perspektive." In Johann Gottfried Herder 1744-1803, edited by Gerhard Sauder, 156-176. Hamburg: Meiner, 1987.

Garrett, Aaron. “Anthropology: The 'Original' of Human Nature," in The Cambridge Companion to the Scottish Enlightenment, edited by Alexander Broadie, 79-93. Cambridge: Cambridge University Press, 2003.

Gwilliam, Tassie. "'Scenes of Horror', Scenes of Sensibility: Sentimentality and Slavery in John Gabriel Stedman's Narrative of a Five Years Expedition against the Revolted Negroes of Surinam," ELH 65, no. 3 (1998): 653-673. 
Häberlein, Mark. "Kulturelle Vermittler in der atlantischen Welt der Frühen Neuzeit." In Sprachgrenzen - Sprachkontakte - Kulturelle Vermittler. Kommunikation zwischen Europäern und Außereuropäern (16.-20. Jahrhundert), edited by Mark Häberlein and Alexander Keese, 177-201. Stuttgart: Steiner, 2010.

Häberlein, Mark. "Augsburger Handelshäuser und die Neue Welt. Interessen und Initiativen im atlantischen Raum (16.-18. Jahrhundert)." In Augsburg und Amerika. Aneignungen und globale Verflechtungen in einer Stadt, edited by Philipp Gassert, Günther Kronenbitter, Stefan Paulus and Wolfgang E.J. Weber, 19-38. Augsburg: Wissner, 2014.

Häberlein, Mark. Aufbruch ins globale Zeitalter: Die Handelswelt der Fugger und Welser. Darmstadt: Theiss, 2016.

Häberlein, Mark. "Matthias Christian Sprengel als Vermittler englischer und romanischer Literatur über die außereuropäische Welt." In Halle als Zentrum der Mehrsprachigkeit im langen 18. Jahrhundert, edited by Mark Häberlein and Holger Zaunstöck, 215-227. Halle: Verlag der Franckeschen Stiftungen, 2017.

Häberlein, Mark, and Schmölz-Häberlein, Michaela. Die Erben der Welser. Der Karibikhandel der Augsburger Firma Obwexer im Zeitalter der Revolutionen. Augsburg: Wissner, 1995.

Harvey, David Allan. The French Enlightenment and its Others: The Mandarin, the Savage, and the Invention of the Human Sciences. New York: Palgrave-Macmillan, 2012.

Hochschild, Adam. Bury the Chains: The British Struggle to Abolish Slavery. London: Macmillan, 2005.

Jones, George Fenwick. The Georgia Dutch: From the Rhine and Danube to the Savannah, 1733-1783. Athens: University of Georgia Press, 1992.

Klarer, Mario. “Humanitarian Pornography: John Gabriel Stedman's Narrative of a Five Years Expedition Against the Revolted Negroes of Surinam (1796)." New Literary History 36, no. 4 (Autumn 2005): 559-587.

Lüsebrink, Hans-Jürgen. "Wissen und außereuropäische Erfahrung im 18. Jahrhundert." In Macht des Wissens. Die Entstehung der modernen Wissensgesellschaft, edited by Richard van Dülmen and Sina Rauschenbach, 629-654. Cologne: Böhlau, 2004.

Mazzolini, Renato G. "Skin Color and the Origin of Physical Anthropology (1640-1850)." In Reproduction, Race, and Gender in Philosophy and the Early Life Sciences, edited by Susanne Lettow, 131-162. Albany: SUNY Press, 2014.

Michel, Paul. Physikotheologie - Ursprünge, Leistung und Niedergang einer Denkform. Zurich: Editions à la Carte, 2008.

Münch, Paul. "Wie aus Menschen Weiße, Schwarze, Gelbe und Rote wurden. Zur Geschichte der rassistischen Ausgrenzung über die Hautfarbe," Essener Unikate 6/7 (1995): 86-97.

Nii Anum Kpobi, David. Saga of a Slave: Jacobus Capitein of Holland and Elmina. Oxford: African Books Collective, 2002.

Oz-Salzberger, Fania. Translating the Environment: Scottish Civic Discourse in Eighteenth-Century Germany. Oxford: Clarendon Press, 1995.

Pečar, Andreas, and Tricoire, Damien, Falsche Freunde: War die Aufklärung wirklich die Geburtsstunde der Moderne? Frankfurt and New York: Campus, 2015.

Pfeuffer, Renate. “. . . manchem Menschen Verdienst, Tausenden aber Belehrung und Vergnügen . . . Die ,Unterhaltungen aus der Naturgeschichte“ des Pfarrers Zu den Barfüßern Gottlieb Tobias Wilhelm (1758-1811)." In Neue Forschungen zur Geschichte der Stadt Augsburg, edited by Rolf Kießling, 231-278. Augsburg: Wissner, 2011.

Price, Richard. “Kwasimukamba’s Gambit,” Bijdragen tot de taal-, land-en volkenkunde 135 (1979): 151-169.

Rajkay, Barbara. “Totentanz oder Maskenbälle? Anmerkungen zur Geschichte Augsburgs im 18. Jahrhundert." In Augsburg, Schwaben und der Rest der Welt: Neue Beiträge zur Landes- 
und Regionalgeschichte. Festschrift für Rolf Kießling zum 70. Geburtstag, edited by Dietmar Schiersner, Andreas Link, Barbara Rajkay and Wolfgang Scheffknecht, 85-109. Augsburg: Wissner, 2011.

Rediker, Marcus. The Slave Ship: A Human History. New York: Viking, 2007.

Reimann, Sarah. Die Entstehung des wissenschaftlichen Rassismus im 18. Jahrhundert. Stuttgart: Steiner, 2017.

Schmieder, Ulrike. "Transkulturation und gender: Stereotypen von masculinity im europäischen Wissenschaftsdiskurs des 18. Jahrhunderts über Lateinamerika." Zeitschrift für Weltgeschichte. Interdisziplinäre Perspektiven 8, no. 2 (2007): 121-151.

Schmölz Häberlein, Michaela: “Cobres, Joseph Paul, Ritter von.” In Stadtlexikon Augsburg. Augsburg: Wissner 2007. Accessed October 22, 2019. https://www.wissner.com/stadtlexikonaugsburg/artikel/stadtlexikon/cobres/3497.

Schüller, Karin. Die deutsche Rezeption haitianischer Geschichte in der ersten Hälfte des 19. Jahrhunderts. Ein Beitrag zum deutschen Bild vom Schwarzen. Cologne: Böhlau, 1992.

Stott, Anne. Wilberforce: Family and Friends. Oxford: Oxford University Press, 2012.

“Trans-Atlantic Slave Trade Estimates.” Voyages: The Trans-Atlantic Slave Trade Database. Accessed June 1, 2019. https://www.slavevoyages.org/assessment/estimates.

Trepp, Anne-Charlott. Von der Glückseligkeit alles zu wissen. Die Erforschung der Natur als religiöse Praxis in der Frühen Neuzeit. Frankfurt: Campus, 2009.

Vetter, Sabine. Wissenschaftlicher Reduktionismus und die Rassentheorie von Christoph Meiners. Ein Beitrag zur Geschichte der verlorenen Metaphysik in der Anthropologie. Aachen: Mainz, 1997.

Wood, Marcus. Blind Memory: Visual Representations of Slavery in England and the Americas, 1780-1865. Manchester and New York: Manchester University Press, 2000. 


\section{0 "We Do Not Need Any Slaves; We Use Oxen and Horses": Children's Letters from Moravian Communities in Central Europe to Slaves' Children in Suriname (1829)}

In 1829, 10-year-old Eugene Hepp of the Moravian community in Königsfeld im Schwarzwald wrote a letter to the children of the community of enslaved Moravians in Paramaribo in Suriname:

Dear brothers,

I want to write you a short letter. Be faithful to your master, and you will not be treated so strictly. And be faithful to your heavenly Father, and everything will become better. We do not need any slaves; we use oxen, horses, etc. for working on the fields. Be faithful to your teacher, go diligently to church, and serve the Lord in heaven until death. And read the Bible obediently and make yourself faithful to the Lord, the Creator.

Farewell, Eugene Hepp ${ }^{1}$

Hepp's greetings from Königsfeld are one of thirty-two short letters now kept at the Moravian Archives in Bethlehem, Pennsylvania that were written by children from German, Swiss, and Dutch Moravian communities to enslaved Moravian children in Suriname (see Fig. 10.1 at the end of this text). They were penned during so-called “children's hours" held by the teacher and prospective missionary Johann Rudolf Passavant in the Moravian communities in Basel in Switzerland, Königsfeld in Württemberg, Ebersdorf in Thuringia, and Zeist in the Netherlands. The letters were relatively formalized, and the issues the children dealt with were limited by the instructions Passavant gave them in his lessons. ${ }^{2}$ The Moravian children mentioned slavery without relating to intellectual debates about abolition and economy - and it is precisely this fact that makes these letters enormously interesting sources, since because they reveal how slavery was perceived and explained in European communities far removed from colonial slaving regions and the mainstream of intellectual and political discourse.

In this contribution, I will discuss to what extent the image of slavery conveyed in these childrens' letters represents discourses on slavery among the Moravian mission of the time. For this purpose - after providing some background information on Moravian historiography, the situation in Suriname, and the information network of the Moravian community and its education - I will analyze the letters with

1 Moravian Archives Bethlehem (MAB), 07 MissSur 01.39.4, Letter from Eugene Hepp in Königsfeld to the children in Suriname, February 1829.

2 On writing the letters as part of Passavant's lessons, see for example MAB, 07 MissSur 01.37.1, Louise and Mari Kramer, February 9, 1829. 